\title{
Radioprotection of targeted and bystander cells by methylproamine
}

\author{
Susanne Burdak-Rothkamm • Andrea Smith • \\ Pavel Lobachevsky $\cdot$ Roger Martin · Kevin M. Prise
}

Received: 1 July 2014 / Accepted: 2 September 2014 / Published online: 23 September 2014

(C) The Author(s) 2014. This article is published with open access at Springerlink.com

\begin{abstract}
Introduction Radioprotective agents are of interest for application in radiotherapy for cancer and in public health medicine in the context of accidental radiation exposure. Methylproamine is the lead compound of a class of radioprotectors which act as DNA binding anti-oxidants, enabling the repair of transient radiation-induced oxidative DNA lesions. This study tested methylproamine for the radioprotection of both directly targeted and bystander cells.

Methods T98G glioma cells were treated with $15 \mu \mathrm{M}$ methylproamine and exposed to ${ }^{137} \mathrm{Cs} \gamma$-ray/X-ray irradiation and $\mathrm{He}^{2+}$ microbeam irradiation. Radioprotection of directly targeted cells and bystander cells was measured by clonogenic survival or $\gamma \mathrm{H} 2 \mathrm{AX}$ assay.
\end{abstract}

Dr. med. S. Burdak-Rothkamm ( $\square)$

Cellular Pathology, Oxford University Hospitals,

Headley Way, Headington,

OX3 9DU, Oxford, UK

e-mail: s.burdakrothkamm@yahoo.co.uk

K. M. Prise · Dr. med. S. Burdak-Rothkamm

Centre for Cancer Research \& Cell Biology,

Queen's University Belfast,

Belfast, UK

A. Smith $\cdot$ P. Lobachevsky $\cdot$ R. Martin

Molecular Radiation Biology Laboratory,

Peter MacCallum Cancer Centre,

VIC, Melbourne, Australia

\section{A. Smith · P. Lobachevsky $\cdot$ R. Martin}

The Sir Peter MacCallum Department of Oncology,

University of Melbourne,

VIC, Melbourne, Australia
Results Radioprotection of directly targeted T98G cells by methylproamine was observed for ${ }^{137} \mathrm{Cs} \gamma$-rays and X-rays but not for $\mathrm{He}^{2+}$ charged particle irradiation. The effect of methylproamine on the bystander cell population was tested for both X-ray irradiation and $\mathrm{He}^{2+}$ ion microbeam irradiation. The X-ray bystander experiments were carried out by medium transfer from irradiated to non-irradiated cultures and three experimental designs were tested. Radioprotection was only observed when recipient cells were pretreated with the drug prior to exposure to the conditioned medium. In microbeam bystander experiments targeted and nontargeted cells were co-cultured with continuous methylproamine treatment during irradiation and postradiation incubation; radioprotection of bystander cells was observed.

Discussion and conclusion Methylproamine protected targeted cells from DNA damage caused by $\gamma$-ray or X-ray radiation but not $\mathrm{He}^{2+}$ ion radiation. Protection of bystander cells was independent of the type of radiation which the donor population received.

Keywords Radioprotection - Methylproamine · Radiation-induced bystander effect $\cdot \gamma \mathrm{H} 2 \mathrm{AX}$. Radiotherapy

\section{Radioprotektive Wirkung von Methylproamine auf direkt bestrahlte Zellen und Bystander-Zellen}

\section{Zusammenfassung}

Einleitung Radioprotektive Agenzien sind sowohl in der Strahlentherapie von Krebserkrankungen als auch im Strahlenschutz im Zusammenhang mit akzidenteller Exposition von Bedeutung. Methylproamine ist die Leitsubstanz einer Klasse von Radioprotektoren, die ihre Wirkung als DNAbindende Antioxidanzien entfalten und so die Reparatur 
von transienten strahleninduzierten oxidativen DNA-Schäden ermöglichen. Die Studie untersucht die radioprotektive Wirkung von Methylproamine auf direkt bestrahlte und Bystander-Zellen.

Methoden T98G-Gliomzellen wurden mit $15 \mu \mathrm{M}$ Methylproamine inkubiert und anschließend mit ${ }^{137} \mathrm{Cs}-\gamma$-Strahlen/ Röntgenstrahlung bzw. $\mathrm{He}^{2+}$-Microbeam-Bestrahlung behandelt. Die Radioprotektion direkt bestrahlter und Bystander-Zellen wurde als klonales Zellüberleben oder im $\gamma \mathrm{H} 2 \mathrm{AX}$-Foci-Assay gemessen.

Ergebnisse Eine radioprotektive Wirkung wurde für T98GGliomzellen nach direkter Bestrahlung mit ${ }^{137} \mathrm{Cs}-\gamma$-und Röntgenstrahlung beobachtet, nicht jedoch nach Bestrahlung mit $\mathrm{He}^{2+}$-Ionen. Der radioprotektive Effekt von Methylproamine auf die Bystander-Population wurde sowohl für Röntgenstrahlung als auch $\mathrm{He}^{2+}$-Microbeam-Bestrahlung untersucht. Die Bystander-Experimente für Röntgenstrahlen wurden mithilfe von Zellkulturmediumtransfers von bestrahlten zu unbestrahlten Zellkulturen durchgeführt, drei verschiedene Experimentdesigns wurden getestet. Radioprotektion wurde nur beobachtet, wenn die Empfängerkultur mit Methylproamine vorbehandelt wurden, bevor sie dem konditionierten Zellkulturmedium ausgesetzt wurden. In den Microbeam-Bystander-Experimenten wurden bestrahlte und unbestrahlte Zellen kokultiviert, und die Behandlung mit Methylproamine erstreckte sich kontinuierlich über den Zeitraum der Bestrahlung und die anschließende Inkubationszeit.

Diskussion und Fazit Methylproamine schützte direkt bestrahlte Zellen vor DNA-Schädigung durch $\gamma$-Strahlen und Röntgenstrahlung, jedoch nicht vor Schäden durch $\mathrm{He}^{2+}-$ Ionen. Die Protektion der Bystander-Zellen war unabhängig von der Art der Bestrahlung, der die Donorpopulation ausgesetzt war.

Schlüsselwörter Radioprotektion - Methylproamine · Strahleninduzierter Bystander-Effekt · $\gamma \mathrm{H} 2 \mathrm{AX} \cdot$ Strahlentherapie

\section{Introduction}

Methylproamine is the lead compound of a new class of radioprotectors related to the commercially available fluorescent DNA stains Hoechst 33258 and Hoechst 33342 (see Fig. 1 for structures). Aside from potential uses in cancer radiotherapy, especially in the context of topical application to normal tissues "at risk" in cancer radiotherapy patients [1-3], such as oral mucosa, rectal mucosa, oesophageal mucosa and skin, there are potential applications for new radioprotectors that extend beyond the oncology arena, involving both planned and unplanned radiation exposures $[4,5]$.

The development of methylproamine and analogues was originally inspired by reports of unexpected radioprotective activity of Hoechst 33342 [6] and modification of the radiation sensitivity of human tumour cells by a bis-benzimidazole derivative was reported by Young et al. [7] and Denison et al. [8]. Guided by a mechanistic hypothesis for the radioprotective activity, analogues of Hoechst 33342 with more electron-rich substituents were synthesised and evaluated, and methylproamine proved to be a more potent radioprotector than Hoechst 33342 [9].

From a mechanistic standpoint methylproamine can be considered as a DNA binding anti-oxidant. Pulse radiolysis experiments support a mechanism involving repair of transient radiation-induced oxidative lesions on DNA, by a process of electron/hole transfer from/to nearby DNAbound drug. This hypothesis is consistent with the results of recent investigations of double-stranded break induction, just an hour after irradiation, as reflected by the appearance of $\gamma \mathrm{H} 2 \mathrm{AX}$ foci, which serve as a sensitive marker for DNA double strand breaks [10]. As previously shown, treatment with methylproamine before and during irradiation reduced the level of radiation-induced $\gamma \mathrm{H} 2 \mathrm{AX}$ foci in cultured keratinocytes, in parallel with a subsequent reduction in the extent of radiation-induced cell-killing [11]. Thus the radioprotection by methylproamine, demonstrated for the clonogenic survival endpoint, can be ascribed to a decrease in the yield of early DNA damage as measured by the foci assay.

A major interest in contemporary radiobiology is the phenomenon of the bystander effect, which describes the
Fig. 1 Methylproamine. The molecular structure of methylproamine and parent ligands are shown in Fig 1; for Hoechst $33342, \mathrm{R}_{1}=\mathrm{H}, \mathrm{R}_{2}=\mathrm{OCH}_{2} \mathrm{CH}_{3}$; for Hoechst 33258, $\mathrm{R}_{1}=\mathrm{H}$, $\mathrm{R}_{2}=\mathrm{OH}$; for methylproamine $\mathrm{R}_{1}=\mathrm{CH}_{3}$ and $\mathrm{R}_{2}=\mathrm{N}\left(\mathrm{CH}_{3}\right)_{2}$

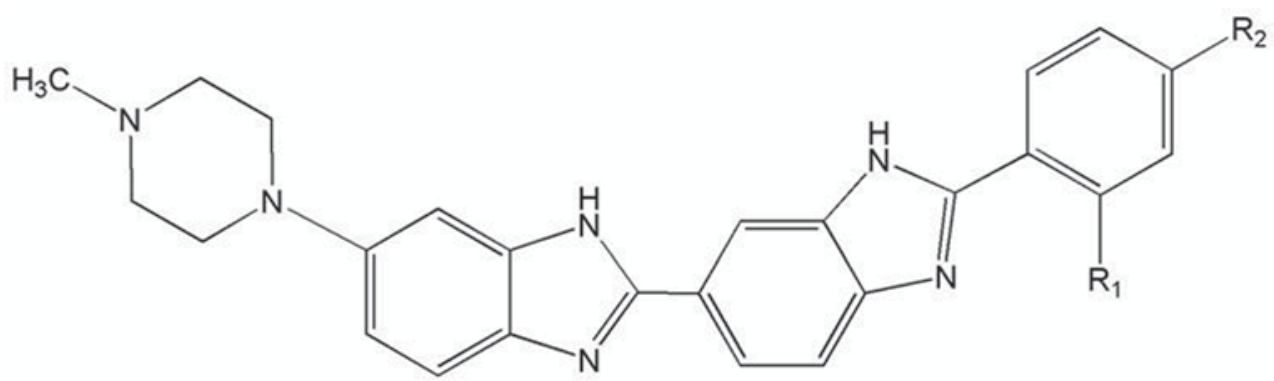


observation that not only irradiated cells, but also the neighbours of the irradiated cells, respond to the effects of ionising radiation, particularly in terms of radiation-induced DNA damage, chromosome damage, mutation and loss of clonogenic viability [12-16]. The availability of microbeam technology has played a key role in the discovery and mechanistic investigation of the bystander effect. An alternative approach to investigate bystander effects are medium transfer experiments where filtered conditioned medium is transferred from irradiated cell cultures to nonirradiated (bystander) cultures. Proposed mechanisms for the propagation of bystander effects are the release of radical oxygen and nitrogen species, cytokines and the induction of a range of intra- and intercellular signalling pathways [17-23]. Radiation-induced bystander effects are currently discussed in the context of their contribution to carcinogenesis [24] and in view of a potential exploitation of bystander effects in cancer therapy [25]. The identification of molecular drug targets in the bystander signalling pathway provides a rationale for a pharmacological modulation of bystander effects [26].

We now report the results of microbeam and medium transfer experiments designed to explore radioprotection by methylproamine in the context of the bystander effect. In short, we address the question: Does methylproamine protect the targeted (irradiated) cells, the bystander cells, or both? Aside from extending the knowledge of the bystander phenomenon, the results also contribute to our understanding of the mechanism of radioprotection. T98G glioma cells were chosen for the study since the techniques to be used for the bystander studies were well-established for these cells. However it was then necessary to undertake separate experiments on the effect of methylproamine on these cells to determine the optimal drug concentration for the bystander studies. From our experience with V79 cells [6] and human keratinocytes [8], exposure to methylproamine is associated with concentration-dependent, and exposure time-dependent cytotoxicity. For example for a human keratinocyte cell line, a $1 \mathrm{~h}$ exposure to $20 \mu \mathrm{M}$ methylproamine reduced clonogenic survival down to about $80 \%$ [8]. Thus a suitable drug concentration was established for T98G cells (namely $15 \mu \mathrm{M}$ ), that provided radioprotection without intolerable cytotoxicity.

\section{Material and methods}

\section{Experimental design}

Radioprotection by methylproamine of directly irradiated and bystander cells was studied using $\gamma \mathrm{H} 2 \mathrm{AX}$ foci as the experimental endpoint for radiation-induced DNA damage. T98G cells were irradiated with $\mathrm{He}^{2+}$ ions or $240 \mathrm{kV} \mathrm{X-rays.}$ The radiation-induced bystander effect was studied in two different protocols-microbeam irradiation and medium transfer. The microbeam experiments used $3 \mathrm{MeV} \mathrm{He}^{2+}$ ions from the Gray Cancer Institute charged particle microbeam [27]. In the medium transfer experiments, donor cells were irradiated with $240 \mathrm{kV}$ X-rays, and medium was transferred to recipient cells after contact with donor cells $30 \mathrm{~min}$ postirradiation. Recipient cells were fixed and processed for $\gamma \mathrm{H} 2 \mathrm{AX} 30$ min later.

Protection of bystander cells was investigated in medium transfer experiments, using three different designs with respect to the addition of methylproamine $(15 \mu \mathrm{M})$ :

- addition to the donor cell population before irradiation and transfer with the filtered conditioned medium,

- addition to the filtered conditioned medium before transfer to the recipient cells or

- pre-incubation with the recipient cell population as well as addition to the transferred medium.

Methylproamine was added to $\mathrm{T} 98 \mathrm{G}$ cells to a concentration of $15 \mu \mathrm{M}$ at $15 \mathrm{~min}$ prior to irradiation (with exception of the medium transfer experiments where the specific treatment protocol is detailed above) and was not removed until 30 min after irradiation when the cells were fixed and processed for $\gamma \mathrm{H} 2 \mathrm{AX}$ immunohistochemistry.

In separate experiments it was established that clonogenic survival for T98G cells exposed to $15 \mu \mathrm{M}$ methylproamine was $>50 \%$ (data not shown) and the protection of T98G cells from ${ }^{137} \mathrm{Cs} \gamma$-ray irradiation by treatment with $15 \mu \mathrm{M}$ methylproamine was shown in a clonogenic assay.

\section{Cell culture conditions}

T98G glioma cells were cultured in RPMI 1640 medium (Cambrex, Verviers, Belgium) supplemented with 10\% FBS (PAA, Pasching, Austria), 2 mM L-glutamine, 100 units $/ \mathrm{ml}$ penicillin and $100 \mu \mathrm{g} / \mathrm{ml}$ streptomycin (all Cambrex, Verviers, Belgium). T98G cells were obtained from the European Collection of Cell Cultures (ECACC). Cells were incubated at $37^{\circ} \mathrm{C}, 5 \% \mathrm{CO}_{2}$ and for all experiments nonconfluent cell cultures were used.

Microbeam irradiation

The Gray Cancer Institute charged particle microbeam system was used for targeted irradiation [27, 28]. Cells were seeded in the centre of Mylar foil dishes pretreated with $1.7 \mu \mathrm{g} / \mathrm{cm}^{2}$ BD Cell-Tak adhesive (Becton Dickinson, Erembodegem, Belgium) and stained in medium containing a $0.8 \mu \mathrm{M}$ concentration of the fluorescent dye Hoechst 33342 (Molecular Probes, Leiden, the Netherlands) to enable visualisation of cell nuclei by fluorescent microscopy at the microbeam stage.

For the study of targeted cells, 1,000 cells were seeded within a volume of $30 \mu 1$ of complete culture medium in the 
central area of the dish and irradiated with a defined number of $\mathrm{He}^{2+}$ ions per nucleus.

Bystander cells were studied as cells adjacent to cells irradiated by a line of 5 helium ions $/ \mu \mathrm{m}$ (approx. 2-3 $\mu \mathrm{m}$ wide) across the culture dish; for bystander experiments 10,000 cells were seeded in the centre of each dish.

Cells were incubated at $37^{\circ} \mathrm{C}, 5 \% \mathrm{CO}_{2}$ for $30 \mathrm{~min}$ after irradiation and prior to fixation.

X-ray irradiation and medium transfer experiments

Cells were irradiated with $240 \mathrm{kV}$ X-rays (Pantak) with $4.3 \mathrm{~mm}$ aluminium filtration $(0.4 \mathrm{~Gy} / \mathrm{min})$. Cells were grown on coverslips sitting in tissue culture dishes. Irradiation and subsequent incubation was performed at $37^{\circ} \mathrm{C}$ to allow foci formation. After $10 \mathrm{~min}$, cells were placed on ice to prevent DNA repair, fixed with $4 \%$ paraformaldehyde and immunostained for $\gamma \mathrm{H} 2 \mathrm{AX}$ foci as described below.

For medium transfer experiments, cells were seeded on $22 \times 22 \mathrm{~mm}^{2}$ coverslips placed in 6-well tissue culture dishes and were treated with filtered medium obtained from cells, which had been irradiated with 2 Gy of X-rays (Pantak, $240 \mathrm{KV}$ ) followed by $30 \mathrm{~min}$ of incubation. The cell culture medium was filtered through a $0.45 \mu \mathrm{m}$ syringe filter in order to prevent the transfer of cells with the supernatant culture medium. The recipient cells were incubated with the conditioned medium at $37^{\circ} \mathrm{C}, 5 \% \mathrm{CO}_{2}$ for further $30 \mathrm{~min}$.

\section{Immunocytochemistry}

For immunocytochemistry, cells were fixed for $15 \mathrm{~min}$ with $4 \%$ paraformaldehyde, permeabilized with $0.5 \%$ Triton-X 100 (both Sigma, Poole, UK) and blocked with 3\% FBS (PAA, Pasching, Austria) in PBS for $30 \mathrm{~min}$ at room temperature. Incubation with a primary antibody specific for $\gamma \mathrm{H} 2 \mathrm{AX}$ (H2AX p139S; Upstate, Chandlers Ford, UK) for $1 \mathrm{~h}$ at room temperature was followed by incubation with a matching Alexa Fluor 488 labelled secondary antibody (Molecular Probes, Leiden, the Netherlands) and nuclear counterstaining with DAPI. Between antibody incubations, cells were washed tree times with PBS $/ 3 \%$ FBS. For cells cultured on coverslips, the inverted coverslip was placed on a glass slide with VectaShield mounting medium for fluorescence microscopy (Vector Laboratories, Burlingame, CA) after staining was completed, and the edges were sealed with clear nail varnish. Cells growing on Mylar foil were stained within the microbeam dish and the foil was glued to a glass slide. A coverslip was placed on top of the Mylar foil with VectaShield mounting medium after staining was completed, and the edges were sealed with nail varnish.

A fluorescence microscope was used for imaging and analysis (Zeiss, Welwyn Garden City, UK). For quanti- fication of foci numbers, individual $\gamma \mathrm{H} 2 \mathrm{AX}$ foci per cell nucleus were counted by eye.

Clonogenic survival assay

Cultures for use in the clonogenic survival assays were in $\log$ phase growth with approximately $1 \times 10^{6}$ cells $/ 25 \mathrm{~cm}^{2}$ flask. The cell number to media volume ratio was kept constant for all experiments $\left(1 \times 10^{6}\right.$ cells $/ 5 \mathrm{ml}$ media $)$. Accordingly, the media volume in the experimental flasks was adjusted after an initial cell number estimation using duplicate spare flasks. Methylproamine was solubilised in $40 \mathrm{mM}$ acetic acid $/ 50 \%$ ethanol and added to the medium in the flasks to give a final concentration of $15 \mu \mathrm{M}$. The flasks were then incubated for $30 \mathrm{~min}$ at $37^{\circ} \mathrm{C}, 5 \% \mathrm{CO}_{2}$ before being irradiated with ${ }^{137} \mathrm{Cs} \gamma$-rays using a Gamma Cell 40 Irradiator (Nordion International, Ottawa, ON, Canada) at a dose rate of $0.56 \mathrm{~Gy} / \mathrm{min}$. Control flasks (containing no methylproamine) were exposed to doses between 0 and 12 Gy while the flasks containing methylproamine were exposed to doses of 0-24 Gy. Following irradiation, flasks were returned to $37^{\circ} \mathrm{C}, 5 \% \mathrm{CO}_{2}$ for the remainder of the incubation period ( $1 \mathrm{~h}$ total incubation).

After the incubation, cells were washed with PBS/EDTA and the monolayer disrupted by treatment with $0.01 \%$ pronase (Merck KGaA, Darmstadt, Germany) in PBS/0.5 mM EDTA (Sigma, St Louis, MO, USA). Following pronase treatment, the pronase was neutralised by the addition of growth media and a single cell suspension was created by repeat pipetting $(20 \times)$ with a $5 \mathrm{ml}$ pipette. The cell suspension was then centrifuged at $1500 \mathrm{rpm}$ (458 rcf) for $5 \mathrm{~min}$, the cell pellet resuspended in growth media and again repeatedly pipetted $(20 \times)$ to form a single cell suspension. Cell numbers were determined using a Z2 Coulter Counter (Beckman Coulter Australia, Gladesville, NSW, Australia).

After determining the cell numbers in each flask, cells were diluted, using serial dilutions, to the appropriate concentration and plated into $60 \mathrm{~mm}$ petri dishes. Five replicates were made from each flask. The petri dishes were then incubated, undisturbed, for 8 days at $37^{\circ} \mathrm{C}$ in a humidified atmosphere of $5 \% \mathrm{CO}_{2}$. The resulting colonies were fixed with neutral formalin before being stained with $0.01 \%$ crystal violet. Colonies containing more than 50 cells were counted by hand using an inverted stereo microscope.

\section{Results}

Effect of treatment with methylproamine on directly irradiated cells

Clonogenic cell survival was determined for T98G glioma cells after single doses of ${ }^{137} \mathrm{Cs} \gamma$-ray irradiation between 

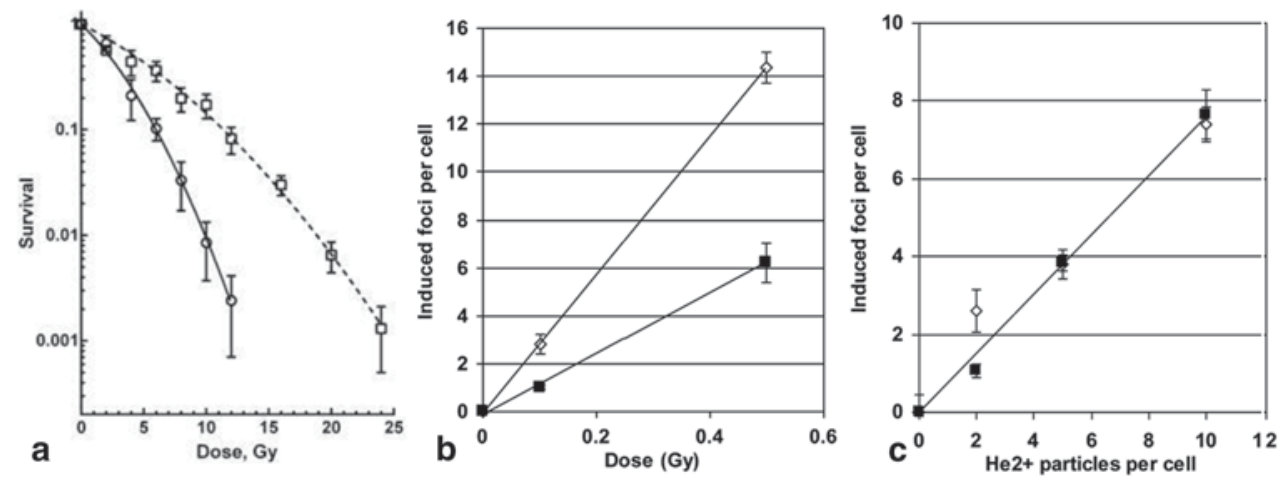

Fig. 2 a Clonogenic survival curves for T98G cells after ${ }^{137} \mathrm{Cs} \gamma$-ray irradiation, with (open squares) and without (open circles) methylproamine treatment $(15 \mu \mathrm{M} ; 15$ min prior to irradiation). The data points show the average and standard deviation for three separate pairs of survival curves. The dose-modifying factor is 2.1. b Effect of methylproamine on $\gamma \mathrm{H} 2 \mathrm{AX}$ foci induction by X-ray irradiation. $15 \mu \mathrm{M}$ methylproamine added $15 \mathrm{~min}$ before radiation (X-ray, $240 \mathrm{kV}$ ). Methylproamine significantly protected against radiation-induced foci in "targeted" T98G cells $(p<0.01$, t-test), in keeping with the results

0 and 12 Gy for cells not treated with methylproamine and doses between 0 and 24 Gy for those protected by methylproamine treatment. Treatment with $15 \mu \mathrm{M}$ of methylproamine - prior to, during and after irradiationsignificantly increased the clonogenic survival of T98G cells. On the basis of these experiments, the extent of radioprotection corresponded to a dose modification factor of 2.1 (Fig. 2a), similar to the results published for the FEP1811 human keratinocyte cell line $[9,11]$.

In order to visualise and quantify radiation-induced DNA damage and the potential protection by methylproamine treatment, the $\gamma \mathrm{H} 2 \mathrm{AX}$ assay was applied which has been previously used as suitable endpoint in bystander studies $[15,29,30]$. T98G glioma cells were irradiated with X-ray doses between 0 and 0.5 Gy and immunofluorescent staining for $\gamma \mathrm{H} 2 \mathrm{AX}$ foci was performed (Fig. 2b). Treatment with $15 \mu \mathrm{M}$ of methylproamine - continuously prior, during and after irradiation - significantly reduced the induction of $\gamma \mathrm{H} 2 \mathrm{AX}$ foci per cell $(p<0.01$, t-test).

In order to study the effect of methylproamine on DNA damage induced by heavy charged particle irradiation on directly targeted cells, cultures of T98G glioma cells were irradiated with $0-10$ particles of $\mathrm{He}^{2+}$ ions per nucleus using the Gray Cancer Institute charged particle microbeam system. A linear increase in the number of $\gamma \mathrm{H} 2 \mathrm{AX}$ foci per cell with increasing radiation dose was observed (Fig. 2c). Treatment with methylproamine could not reduce the number of $\mathrm{He}^{2+}$-induced $\gamma \mathrm{H} 2 \mathrm{AX}$ foci in directly irradiated cells, indicating that no protection was achieved from DNA damage by $\mathrm{He}^{2+}$ ion irradiation. shown for the clonogenic survival endpoint. A total of 1006 cells were evaluated. The background foci level in the control cell population was subtracted from the foci count. Error bars represent the standard error of the mean $(S E M)$. c Methylproamine treatment $(15 \mu \mathrm{M}$, added 15 min before radiation) had no effect on $\gamma \mathrm{H} 2 \mathrm{AX}$ foci induction by $\mathrm{He}^{2+}$ microbeam irradiation in "targeted" T98G cells. A total of 336 cells were evaluated. The background foci level in the control cell population was subtracted from the foci count. Error bars represent the SEM

Protection of bystander cells from radiation-induced DNA damage by methylproamine

To investigate the effect of methylproamine on X-rayinduced $\gamma \mathrm{H} 2 \mathrm{AX}$ foci formation in bystander cells, a medium transfer assay was applied and filtered cell culture medium was transferred from an irradiated cell culture to a nonirradiated one. Three different treatment protocols were chosen: Methylproamine was (1) added to the donor cell population before irradiation and transferred with the filtered conditioned medium, (2) added to the filtered conditioned medium before transfer to the recipient cells, or (3) preincubated with the recipient cell population and also added to the transferred medium.

T98G cells that were incubated with filtered medium derived from the irradiated donor cells showed significant induction of bystander $\gamma \mathrm{H} 2 \mathrm{AX}$ foci [Fig 3a (upper image) and $3 \mathrm{~b}$ (column 1)], consistent with our previous studies $[14,15]$. Following treatment with methylproamine according to the three different protocols detailed above, a significant reduction of medium transfer-induced bystander $\gamma \mathrm{H} 2 \mathrm{AX}$ foci was only seen when the recipient bystander cells were pre-incubated with $15 \mu \mathrm{M}$ of methylproamine and methylproamine was also added to the transferred filtered medium ( $p<0.01$, t-test) [Fig. 3a (lower image) and 3b (column 4)]. The two other protocols where the donor cells were pretreated or the agent was only added at the time of medium transfer did not prevent the induction of $\gamma \mathrm{H} 2 \mathrm{AX}$ foci in the recipient bystander cell population (Fig. 3b, columns 2 and 3). This observation supports the hypothesis that methylproamine has to form a complex with the DNA molecule in order to protect the DNA from oxidative damage. 


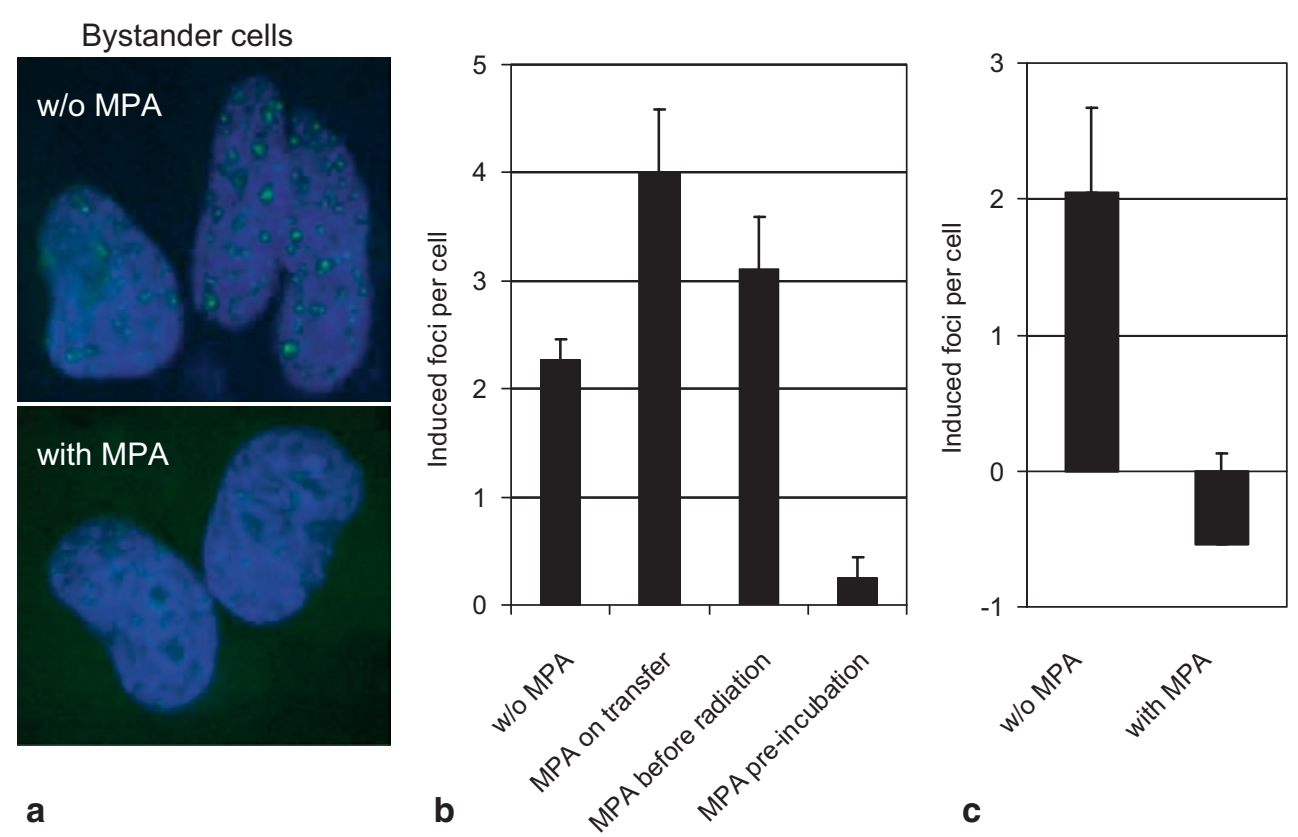

Fig. 3 Effect of methylproamine (MPA) on the induction of $\gamma \mathrm{H} 2 \mathrm{AX}$ bystander foci by medium transfer from X-ray irradiated cells and $\mathrm{He}^{2+}$ microbeam bystander cultures. a Bystander $\gamma \mathrm{H} 2 \mathrm{AX}$ foci are present in T98G cells treated with conditioned medium derived from X-ray (2 Gy) irradiated cells. Pretreatment with methylproamine markedly reduced $\gamma \mathrm{H} 2 \mathrm{AX}$ bystander foci induction. b A significant X-ray (2 Gy) induced bystander effect was seen in cells without methylproamine treatment (column $1 ; p<0.01$, t-test). Three different protocols were applied for the investigation of the effect of methylproamine on the bystander effect: Methylproamine added to the filtered conditioned medium before transfer to the recipient cells (column 2), added to the donor cell population before irradiation and transferred with the filtered conditioned medium (column 3), or pre-incubated with the recipient cell population and also added to the transferred medium (column
4). Pretreatment of recipient cells with methylproamine (15 $\mu \mathrm{M})$ suppressed foci induction by conditioned medium from $\mathrm{X}$-ray irradiated cells $(p<0.05$, t-test) whereas the two alternative treatment protocols without pre-incubation had no significant effect. A total of 1474 cells were evaluated. The background foci level in the control cell population was subtracted from the foci count. Error bars represent the standard error of the mean (SEM). c Methylamine treatment $(15 \mu \mathrm{M})$ prevented $\mathrm{He}^{2+}$ microbeam irradiation-induced $\gamma \mathrm{H} 2 \mathrm{AX}$ bystander foci. A total of 414 cells were evaluated. The background foci level in the control cell population was subtracted from the foci count; the cause of the small negative value for the "induced foci" in the methylaminetreated sample is the correction for background levels. Error bars represent the SEM
In order to study the protection of bystander cells from radiation induced DNA damage by heavy charged particle irradiation, T98G cells were irradiated with a line of $5 \mathrm{He}^{2+}$ ions per $\mu \mathrm{m}$, hitting cells growing in the area of this target line. Bystander cells, i.e. cells adjacent to this line of irradiated cells, showed a marked increase in the average numbers of $\gamma \mathrm{H} 2 \mathrm{AX}$ foci per cell (Fig. 3c; column 1). Treatment with $15 \mu \mathrm{M}$ methylproamine lead to a significant reduction of $\mathrm{He}^{2+}$-induced $\gamma \mathrm{H} 2 \mathrm{AX}$ foci in the bystander cells (column 2 ; $p<0.05$, t-test), similar to the effect of methylproamine observed for the bystander population in X-ray treated cells.

\section{Discussion}

The results presented in this study confirm that methylproamine protects cultured cells from radiation-induced DNA damage. While the protective effect for directly irradiated cells was dependent on the quality of the irradiation and applied to $\mathrm{X}$-irradiation but not to irradiation with $\mathrm{He}^{2+}$ ions, bystander cells were shielded from indirectly induced DNA damage in both settings.

The cytotoxic effect of ionizing radiation is elicited largely by DNA damage attributed to the production of highly reactive radicals such as hydroxyl and superoxide radicals, in combination with direct ionisation events in DNA. Different qualities of ionising radiation cause different patterns of DNA damage. Low linear energy transfer (LET) radiation such as X-rays and $\gamma$-rays causes dispersed DNA damage including single strand breaks, base oxidation and occasional double strand breaks. In contrast, irradiation with high LET charged particles results in clustered DNA damage with frequent double strand breaks and complex patterns of DNA damage [31].

In order to understand the mechanisms underlying the radioprotective effect of methylproamine in directly targeted and bystander cell populations, these results need to be discussed in the context of the hypothesised mode of action of methylproamine. Based on pulse radiolysis studies it is concluded that radioprotection by DNA-binding ligands 
like methylproamine is mediated by repair of a transient oxidising lesion on DNA, by electron/hole transfer [32]. It is proposed that after direct or indirect ionisation of a base, or base pair [33], the "injected" hole migrates along DNA [34]. The bound ligand acts as a reducing agent, contributing an electron to neutralise the hole. In the context of DNA damage and cytotoxicity, the initial lesion is evidently more damaging than the oxidised ligand species. The requirement for pre-incubation of cells with methylproamine prior to exposure to X-ray irradiation or conditioned medium supports this hypothesis as complex formation between radioprotective agent and DNA molecule is required. Oxidative DNA damage is an important mechanism for the cytotoxicity of ionising radiation and also for bystander effects. In bystander cells it is postulated that increased levels of oxidised DNA damage leads to an increased probability of stalled replication forks and consequential DNA DSB [15]. Methylproamine can quickly repair oxidised lesions if it is closely associated with the DNA molecule at the time of radiation. However, with high LET radiation, the molecular density of clustered lesions could exceed the capacity of the charge transfer mechanism. Repair of each lesion requires a separate DNA-bound methylproamine molecule, and a limited number of bound ligand molecules will be within the physical range of the charge transfer process. This expectation of a limited ability of methylproamine to confer radiation protection of high LET radiation provides an explanation for an early report [35] of poor radioprotection by proamine [a close analogue of methylproamine; Fig 1; $\mathrm{R}_{1}=\mathrm{CH}_{3}$ and $\mathrm{R}_{2}=\mathrm{N}\left(\mathrm{CH}_{3}\right)_{2}$ ] of cultured cells irradiated by thermal neutrons in the presence of ${ }^{10} \mathrm{~B}$-borate (boron neutron capture generates high LET fission products) in the cell culture medium.

Based on the results of the present study, it is concluded that methylproamine protects both directly targeted and bystander cell populations from DNA damage induced by X-ray irradiation. However for high LET radiation, bystander but not targeted cells are protected by methylproamine. The chemical identity of the transient lesions involved in protection of targeted cells is the subject of speculation. Much less is known about the chemical nature of DNA lesions induced in bystander cells, compared to the considerable data for targeted cells. Accordingly, even less can be proposed about the mechanism of protection of bystander cells by methylproamine.

Interestingly, the treatment with methylproamine reduced the number of background foci in unirradiated $\mathrm{T} 98 \mathrm{G}$ glioma cells (data not shown) suggesting that intrinsic ROS levels contribute to background level of $\gamma \mathrm{H} 2 \mathrm{AX}$ foci in a given tumour cell line.

Protective effects of methylproamine and related agents may also have relevance in other situations where oxidative stress mediated responses are involved. ROS-medi- ated genotoxic effects are thought to play a central role in processes like aging and carcinogenesis. Recently, ROS/ NOS- and cytokine-mediated DNA damage detected by the $\gamma \mathrm{H} 2 \mathrm{AX}$ assay was described in chronic inflammatory conditions, aging/senescence and in association with cancer [36-40].

There has been significant interest in the potential role of bystander signalling in therapeutic response both with a view to determining its clinical impact on tumour cell killing and potential carcinogenic effects in surrounding normal tissues $[25,26]$. If these responses are potentially deleterious, agents such as methyproamine could play a role in treatment strategies for the use of ion beam approaches to preferentially protect surrounding normal tissues from the impacts of bystander signalling.

It is an interesting thought that radioprotective agents like methylproamine may also become a useful therapeutic option to prevent DNA damage caused by genotoxic stress in contexts other than radiation exposure.

\section{Compliance with ethical guidelines}

Acknowledgements Part of this work was supported by Cancer Research UK (C1513/A7047). The authors are grateful to Stuart Gilchrist for his assistance with the microbeam experiments.

Conflict of intererst S. Burdak-Rothkamm, A. Smith, P. Lobachevsky, R. Martin and K.M. Prise state that there are no conflicts of interest.

This article does not contain any studies on humans or animals.

Open Access This article is distributed under the terms of the Creative Commons Attribution Noncommercial License which permits any noncommercial use, distribution, and reproduction in any medium, provided the original author(s) and the source are credited.

\section{References}

1. Schneider RA, Vitolo V, Albertini F et al (2013) Small bowel toxicity after high dose spot scanning-based proton beam therapy for paraspinal/retroperitoneal neoplasms. Strahlenther Onkol 189:1020-1025

2. Maier P, Wenz F, Herskind C (2014) Radioprotection of normal tissue cells. Strahlenther Onkol 190:745-752

3. Wygoda A, Rutkowski T, Hutnik M et al (2013) Acute mucosal reactions in patients with head and neck cancer. Three patterns of mucositis observed during radiotherapy. Strahlenther Onkol 189:547-551

4. Citrin D, Cotrim AP, Hyodo F et al (2010) Radioprotectors and mitigators of radiation-induced normal tissue injury. Oncologist $15: 360-371$

5. Bourgier C, Levy A, Vozenin MC et al (2012) Pharmacological strategies to spare normal tissues from radiation damage: useless or overlooked therapeutics? Cancer Metastasis Rev 31:699-712

6. Smith PJ, Anderson CO (1984) Modification of the radiation sensitivity of human tumour cells by a bis-benzimidazole derivative. Int J Radiat Biol Relat Stud Phys Chem Med 46:331-344 
7. Young SD, Hill RP (1989) Radiation sensitivity of tumour cells stained in vitro or in vivo with the bisbenzimide fluorochrome Hoechst 33342. Br J Cancer 60:715-721

8. Denison L, Haigh A, D’Cunha G et al (1992) DNA ligands as radioprotectors: molecular studies with Hoechst 33342 and Hoechst 33258. Int J Radiat Biol 61:69-81

9. Martin RF, Broadhurst S, Reum ME et al. (2004) In vitro studies with methylproamine: a potent new radioprotector. Cancer Res 64:1067-1070

10. Rogakou EP, Pilch DR, Orr AH et al (1998) DNA double-stranded breaks induce histone $\mathrm{H} 2 \mathrm{AX}$ phosphorylation on serine 139. J Biol Chem 273:5858-5868

11. Lobachevsky PN, Vasireddy RS, Broadhurst S et al (2011) Protection by methylproamine of irradiated human keratinocytes correlates with reduction of DNA damage. Int J Radiat Biol 87:274-283

12. Azzam EI, De Toledo SM, Spitz DR et al. (2002) Oxidative metabolism modulates signal transduction and micronucleus formation in bystander cells from alpha-particle-irradiated normal human fibroblast cultures. Cancer Res 62:5436-5442

13. Chaudhry MA (2006). Bystander effect: Biological endpoints and microarray analysis. Mutat Res 597:98-112

14. Burdak-Rothkamm S, Rothkamm K, Prise KM (2008) ATM acts downstream of ATR in the DNA damage response signaling of bystander cells. Cancer Res 68:7059-7065

15. Burdak-Rothkamm S, Short SC, Folkard M et al (2007) ATRdependent radiation-induced gammaH2AX foci in bystander primary human astrocytes and glioma cells. Oncogene 26:993-1002

16. Sokolov MV, Smilenov LB, Hall EJ et al (2005) Ionizing radiation induces DNA double-strand breaks in bystander primary human fibroblasts. Oncogene 24:7257-7265

17. Shao C, Stewart V, Folkard M et al (2003) Nitric oxide-mediated signaling in the bystander response of individually targeted glioma cells. Cancer Res 63:8437-8442

18. Shao C, Folkard M, Prise KM (2008) Role of TGF-beta1 and nitric oxide in the bystander response of irradiated glioma cells. Oncogene 27:434-440

19. Han W, Chen S, Yu KN et al (2010) Nitric oxide mediated DNA double strand breaks induced in proliferating bystander cells after alpha-particle irradiation. Mutat Res 684:81-89

20. Hei TK (2006) Cyclooxygenase-2 as a signaling molecule in radiation-induced bystander effect. Mol Carcinog 45:455-460

21. Tartier L, Gilchrist S, Burdak-Rothkamm S et al (2007) Cytoplasmic irradiation induces mitochondrial-dependent 53BP1 protein relocalization in irradiated and bystander cells. Cancer Res 67:5872-5879

22. Zhou H, Ivanov VN, Lien YC et al (2008) Mitochondrial function and nuclear factor-kappaB-mediated signaling in radiationinduced bystander effects. Cancer Res 68:2233-2240

23. Lyng FM, Howe OL, McClean B Reactive oxygen species-induced release of signalling factors in irradiated cells triggers membrane signalling and calcium influx in bystander cells. Int J Radiat Biol $87: 683-695$
24. Mothersill C, Seymour C (2003) Radiation-induced bystander effects, carcinogenesis and models. Oncogene 22:7028-7033

25. Prise KM, O'Sullivan JM (2009) R0adiation-induced bystander signalling in cancer therapy. Nat Rev Cancer 9:351-360

26. Burdak-Rothkamm S, Prise K (2009) New molecular targets in radiotherapy: DNA damage signalling and repair in targeted and non-targeted cells. Eur J Pharmacol 625:151-155

27. Folkard M, Vojnovic B, Prise KM et al (1997) A charged-particle microbeam: I. Development of an experimental system for targeting cells individually with counted particles. Int J Radiat Biol 72:375-385

28. Folkard M, Vojnovic B, Hollis KJ et al (1997) A charged-particle microbeam: II. A single-particle micro-collimation and detection system. Int J Radiat Biol 72:387-395

29. Sedelnikova OA, Nakamura A, Kovalchuk O et al (2007) DNA double-strand breaks form in bystander cells after microbeam irradiation of three-dimensional human tissue models. Cancer Res 67:4295-4302

30. Han W, Wu L, Chen S et al (2007) Constitutive nitric oxide acting as a possible intercellular signaling molecule in the initiation of radiation-induced DNA double strand breaks in non-irradiated bystander cells. Oncogene 26:2330-2339

31. Goodhead DT (1994) Initial events in the cellular effects of ionizing radiations: clustered damage in DNA. Int $\mathrm{J}$ Radiat Biol 65:7-17

32. Martin RF, Anderson RF (1998) Pulse radiolysis studies indicate that electron transfer is involved in radioprotection by Hoechst 33342 and methylproamine. Int J Radiat Oncol Biol Phys 42:827-831

33. Shinde S, Maroz A, Hay M et al (2009) One-electron reduction potential of the neutral guanyl radical in the GC base pair of duplex DNA. J Am Chem Soc 131:5203-5207

34. Giese B (2002) Long-distance electron transfer through DNA. Annu Rev Biochem 71:51-70

35. Martin R, Hendley J, Carolan M (1997) DNA-binding radioprotectors: Active with low but not high-LET radiation. Advances in Neutron Capture Therapy Volume 2. Chemistry and Biology :604-608

36. Sedelnikova OA, Redon CE, Dickey JS et al (2010) Role of oxidatively induced DNA lesions in human pathogenesis. Mutat Res 704:152-159

37. Dickey JS, Baird BJ, Redon CE et al (2009) Intercellular communication of cellular stress monitored by gamma-H2AX induction. Carcinogenesis 30:1686-1695

38. Martin OA, Redon CE, Nakamura AJ et al (2011) Systemic DNA damage related to cancer. Cancer Res 71:3437-3441

39. Redon CE, Dickey JS, Nakamura AJ et al (2010) Tumors induce complex DNA damage in distant proliferative tissues in vivo. Proc Natl Acad Sci U S A 107:17992-17997

40. Redon CE, Nakamura AJ, Martin OA et al (2011) Recent developments in the use of gamma-H2AX as a quantitative DNA doublestrand break biomarker. Aging (Albany NY) 3:168-174 